8168; Fax: 27 (46) 622 4377; E-mail: r.cross@ ru.ac.za; Info: http://www.icem15.com].

\section{2-4 September 2002}

IMA 2002 International Mineralogical Association. Edinburgh, Scotland, UK. [Contact: Marco Pasero, Dipartimento di Scienze della Terra, Via S. Maria 53, 56126 Pisa, Italy. E-mail: pasero@dst.unipi.it; Info: http://www.dst.unipi.it/ ima].

\section{2-26 September 2002}

116th AOAC International Annual Meeting. Los Angeles, California, USA. [Contact: Maria Donovan, AOAC International, 481 North Frederick Avenue, Suite 500, Gaithersburg, MD 20877-2417, USA. Tel: 1 (301) 924 7089; Fax: 1 (301) 924 7089; E-mail: mdonovan@aoac.org; Info: http:// www.aoac.org/].

\section{2-6 December 2002}

Fall Meeting of the Materials Research Society. Boston, Massachusetts, USA. [Contact: Materials Research Society, 506 Keystone Drive, Warrendale, PA 15086-7573, USA. Tel: 1 (724) 779 3003; Fax: 1 (724) 779 8313; E-mail: info@mrs.org; Info: http://www.mrs.org].
30 July-3 August 2003

Microscopy and Microanalysis 2003. San Antonio, Texas, USA. Sponsored by the Microscopy Society of America and the Microbeam Analysis Society. [Contact: MSA Business Office, Bostrom Corporation, 230 East Ohio, Suite 400, Chicago, IL 60611, USA. Tel: 1 (312) 644 1527; Fax: 1 (312) 644 8557; E-mail: businessoffice@ msa.microscopy.com; Info: http://www.msa.microscopy.com].

\section{August/September 2003}

Euroclay 2003. Modena, Italy. [Contact: Maria Franca Brigatti, Dipartimento di Scienza della Terra, Università di Modena e Reggio Emilia, Largo S. Eufemia 19, 41100 Modena, Italy. Fax: 39 (059) 205 5887; E-mail: ec2003@unimo.it; Info: http://www.unimo.it/euroclay2003/ lfr.html].

\section{2-6 September 2003}

ECNS 2003 European Conference on Neutron Scattering. Montpellier, France. [Contact: René Vacher, CNRS-SPM, Montpellier, France. Tel: 33 (4) 6714 3449; Fax: 33 (4) 6714 3498; E-mail: rene@ldv.uni-montp2.fr; Info: http:// www.sfn.asso.fr].

\title{
Short Courses and Workshops
}

\section{March-6 April 2001}

Eighth Intensive Course in $\mathbf{X}$-ray Structural Analysis. Durham, England, UK. Under the sponsorship of the Chemical Crystallography Group of the British Crystallographic Association. [Contact: Prof. Judith A. K. Howard, Department of Chemistry, University of Durham, Durham DH1 3LE, UK. Tel: 44 (191) 374 4647; Fax: 44 (191) 374 3745; E-mail: j.a.k.howard@durham.ac.uk].

\section{April-4 May 2001}

ICDD X-ray Clinic: Fundamentals of X-ray Fluorescence. Newtown Square, Pennsylvania, USA. The first week of an integrated two-week course in the theoretical fundamentals and experimental techniques of X-ray fluorescence spectrometry, including both qualitative and quantitative analysis. [Contact: Education Coordinator, International Centre for Diffraction Data, 12 Campus Boulevard, Newtown Square, PA 19073-3273, USA. Tel: 1 (610) 325 9814; Fax: 1 (610) 325 9823; E-mail: clinics@icdd.com; Info:http://www.icdd.com/education/xrf.htm].

\section{6-10 May 2001}

EMAS 2001 Seventh European Workshop on Modern Developments and Applications in Microbeam Analysis. Tampere, Finland. [Contact: EMAS Secretariat, University of Antwerp (UIA), Department of Chemistry, B-2610 Antwerp-Wilrijk, Belgium. Tel/Fax: 32 (3) 820 2376; E-mail: vantdack@uia.ua.ac.be; Info: http:// www.ssp.gla.ac.uk/emas/emas2001/ first_announcement_p1.htm].

\section{7-11 May 2001}

ICDD X-ray Clinic: Advanced Methods in X-ray Fluorescence. Newtown Square, Pennsylvania, USA. The second week of an integrated two-week course in the theoretical fundamentals and experimental techniques of X-ray fluorescence spectrometry, including both qualitative and quantitative analysis. [Contact: Education Coordinator, International Centre for Diffraction Data, 12 Campus Boulevard, Newtown Square, PA 19073-3273, USA. Tel: 1 (610) 325 9814; Fax: 1 (610) 325 9823; E-mail: clinics@icdd.com; Info: http://www.icdd.com/education/xrf.htm].

\section{4-8 June 2001}

ICDD X-ray Clinic: Fundamentals of X-ray Powder Diffraction. Newtown Square, Pennsylvania, USA. The first week of an integrated two-week course in theoretical and experimental X-ray powder diffraction. This first session is directed to both relative newcomers in the field and to more experienced users who want to broaden their understanding of fundamental concepts and established procedures. [Contact: Education Coordinator, International Centre for Diffraction Data, 12 Campus Boulevard, Newtown Square, PA 19073-3273, USA. Tel: 1 (610) 325 9814; Fax: 1 (610) 325 9823; E-mail: clinics@ icdd.com; Info: http://www.icdd.com/ education/xrd.htm].

\section{1-15 June 2001}

ICDD X-ray Clinic: Advanced Methods in X-ray Powder Diffraction. Newtown Square, Pennsylvania, USA. The second week of an integrated two-week course in theoretical 
and experimental X-ray powder diffraction. This session is designed for the experienced user and focuses on computerbased methods of qualitative and quantitative phase analysis. Previous attendance at the first session is recommended. [Contact: Education Coordinator, International Centre for Diffraction Data, 12 Campus Boulevard, Newtown Square, PA 19073-3273, USA. Tel: 1 (610) 325 9814; Fax: 1 (610) 325 9823; E-mail: clinics@icdd.com; Info: http:// www.icdd.com/education/xrd.htm].

\section{3-15 June 2001}

Tenth Annual Fibre Diffraction and Non-crystalline Diffraction Workshop. Stirling, Scotland, UK. [Contact: Dr. T. Forsyth, BCA CCP13 Chair, Institut Laue Langevin, 6 rue Jules Horowitz, F-38042 Grenoble Cedex 9, France. Tel: 33 (4) 7620 7158; E-mail: tforsyth@ill.fr; Info: http:// www.dl.ac.uk/srs/CCP13].

\section{4-29 July 2001}

School on Crystal Growth. Kyoto, Japan. Held at Doshisha University just prior to the 13th International Conference on Crystal Growth. [Contact: Secretariat ICCG-13/ICVGE11, Faculty of Engineering, Doshisha University, Kyotanabecity, Kyoto 610-0321, Japan. Tel: 81 (774) 656 329; Fax: 81 (774) 656 811; E-mail: info@iccg.doshisha.ac.jp; Info: http://iccg.doshisha.ac.jp/home.html].

\section{7-19 September 2001}

Workshop on Sources of Measurement Error in Electron Beam X-ray Microanalysis. Gaithersburg, Maryland, USA. A NIST event. [Contact: Dale E. Newbury, National Institute of Standards and Technology, 100 Bureau Drive, Stop 8371, Gaithersburg, MD 20899-8371, USA. Tel: 1 (301) 975 3921;
Fax: 1 (301) 417 1321; E-mail: dale.newbury@ nist.gov; Info: http://www.nist.gov/public_affairs/confpage/ 010917.htm].

\section{7-28 September 2001}

Scuola Nazionale di Luce di Sincrotrone. Santa Margherita di Pula (Cagliari), Italy. The directors will be Profs. Settimio Mobilio and Gilberto Vliac. [Contact: Info: http:// www.csmtbo.mi.CNR.it/aic/convegni.html].

\section{2-6 December 2001}

Analysis of Microstructure and Residual Stress by Diffraction Methods. Trento, Italy. Held at the University of Trento. [Contact: Info: http://bragg.ing.unitn.it/sizestrain].

\section{May-8 June 2003}

High Pressure Crystallography. Erice, Italy. The 34th crystallographic course at the Ettore Majorana Centre. The course director is Prof. Andrzej Katrusiak, Adam Mickiewicz University, Department of Crystal Chemistry, ul. Grunwaldzka 6, 60780 Poznan, Poland. Tel: 48 (61) 869 9181; Fax: 48 (61) 865 8008; E-mail: katran@amu.edu.pl; Info: http://www.geomin.unibo.it/orgv/erice/highpres.htm].

26 May-6 June 2004

Polymorphism: Solvates and Phase Relationships. Erice, Italy. The 35th crystallographic course at the Ettore Majorana Centre. The course director is Prof. Joel Bernstein of Ben Gurion University, Israel. [Contact: Prof. Lodovico Riva di Sanseverino, University of Bologna, Department of Earth and Environmental Sciences, Piazza Porta S Donato 1, 40126 Bologna, Italy. Tel: 39 (051) 243 556; Fax: 39 (051) 243 336; E-mail: riva@geomin.unibo.it; Info: http:// www.geomin.unibo.it/orgv/erice/bernstei.htm]. 